\title{
Petrology and depositional environment of the Foord seam, Pictou Coalfield, Nova Scotia
}

\author{
G.M. Yeo \\ Department of Geology, Acadia University, Wolfville, Nova Scotia BOP IXO, Canada
}

\author{
Date Received May 25, 1988 \\ Date Accepted August 15, 1988
}

\begin{abstract}
The Pictou Coalfield is one of several coal deposits in the northem Appalachians. This coalfield is of particular interest because: (1) it is restricted to a synsedimentary, pull-apart graben, (2) the coals are in a late Westphalian lacustrine - deltaic sequence with minor fluvial deposits, (3) it also contains numerous organic-rich shales, and (4) in spite of its small size and long history of mining it remains among the most important coal reserves in the region. The Foord seam is the most important of several seams that have been mined.

In contrast with typical (fluvial basin) Appalachian coals, the Pictou coals are characterized by microbanding, comparatively high rank, low sulphur, and relatively high ash content. Macroscopic appearance and relative proportions of maceral groups (vitrinite $>$ inertinite > liptinite) indicate broad petrographic uniformity within the Foord seam, but the proportions of individual macerals vary widely, reflecting environmental and diagenetic changes. Specific maceral ratios confirm evidence from lithotype studies for cylic development of wet forest swamp, fen, and limnic conditions in response to altemate flooding and drying trends during peat accumulation. Although secular coal facies variations within the Foord seam can be correlated laterally, differences in maceral distribution indicate that depositional and diagenetic conditions must have been locally variable.
\end{abstract}

Le bassin houiller de Pictou est l'un des gisements de charbon du nord des Appalaches. Il présente un intérêt particulier car: (1) il est confiné à un graben rhomboédrique synsédimentaire, (2) les charbons font partie d'une série lacustro-deltaïque tardiwestphalienne incorporant de faibles dépôts fluviatiles, (3) on y rencontre plusieurs shales riches en matière organique, et (4) en dépit de sa faible dimension et d'une exploitation prolongée, ce bassin demeure l'une des plus importantes réserves de charbon de la région. Le faisceau charbonneux de Foord est le plus important à avoir été exploité.

Contrairement aux charbons appalachiens typiques des bassins fluviatiles, les charbons de Pictou sont caractérisés par une microlamination, une classe assez haute, une teneur faible en soufre et relativement élevée en cendres. L'allure macroscopique et la proportion relative des différents groupes de macéraux (vitrinite > inertinite > liptinite) indiquent une uniformité pétrographique générale au sein du faisceau de Foord. Cependant la proportion de chaque macéral varie fortement, ce qui reflète des changements dans le milieu et la diagénèse. Les rapports spécifiques des macéraux confirment les arguments qu'apportent les études des lithotypes en faveur d'un développement cyclique de conditions de marécages de forêt humide, de fens et de conditions limniques en réponse à des tendances alternant entre les inondations et les assèchements durant l'accumulation de la tourbe. Quoiqu'on puisse corréler latéralement les variations séculaires des faciès charbonneux au sein du faisceau de Foord, la distribution différente des macéraux démontre que les conditions diagénétiques et de dépôt devaient varier localement.

[Traduit par le journal]

\section{INTRODUCTION}

The Pictou Coalfield lies in north-central Nova Scotia (Fig. 1a, b). It is restricted to Stellarton Graben (Yeo and Gao, 1986, 1987), a synsedimentary pull-apart graben $6 \mathrm{~km}$ wide by $20 \mathrm{~km}$ long, bounded by the easternmost extension of the Cobequid Fault and the westernmost extension of the Hollow Fault (Fig. 1c).

Although relatively small, the Pictou Coalfield is historically second only to the Sydney Coalfield as the most important coal deposit in eastern Canada. Coal was discovered here in the late 1700 s and has been mined continuously since 1827 (Bell, 1940; Cameron, 1974; and others). Total production is estimated at about 53 million tonnes. Total remaining resources are estimated at about 62 million tonnes of high volatile A bituminous and medium volatile bituminous coal (Hacquebard, 1979).
The Pictou Coalfield also contains a large volume of organic-rich shales. At the Fraser mine south of Stellarton and the Patrick mine on McLellan's Brook such shales werc mined for coal-oil between 1859 and 1861 (Cameron, 1974, pp. 93-94). Although interest in these has recently been revived (Naylor and Smith, 1986; Kalkreuth and Macauley, 1987), they are considered to have no immediate economic potential.

To augment earlier petrographic investigations of the Pictou coals (Hacquebard and Donaldson, 1969; Calder, 1979), studies of coal macerals were undertaken to compare selected coal seams in more detail, to investigate lateral variablity within seams, and to refine ideas about the depositional settings of the coals and their effect on coal quality. The petrography of the Pictou coals is summarized below, but the emphasis of this report is on the lateral variation within the Foord seam. 


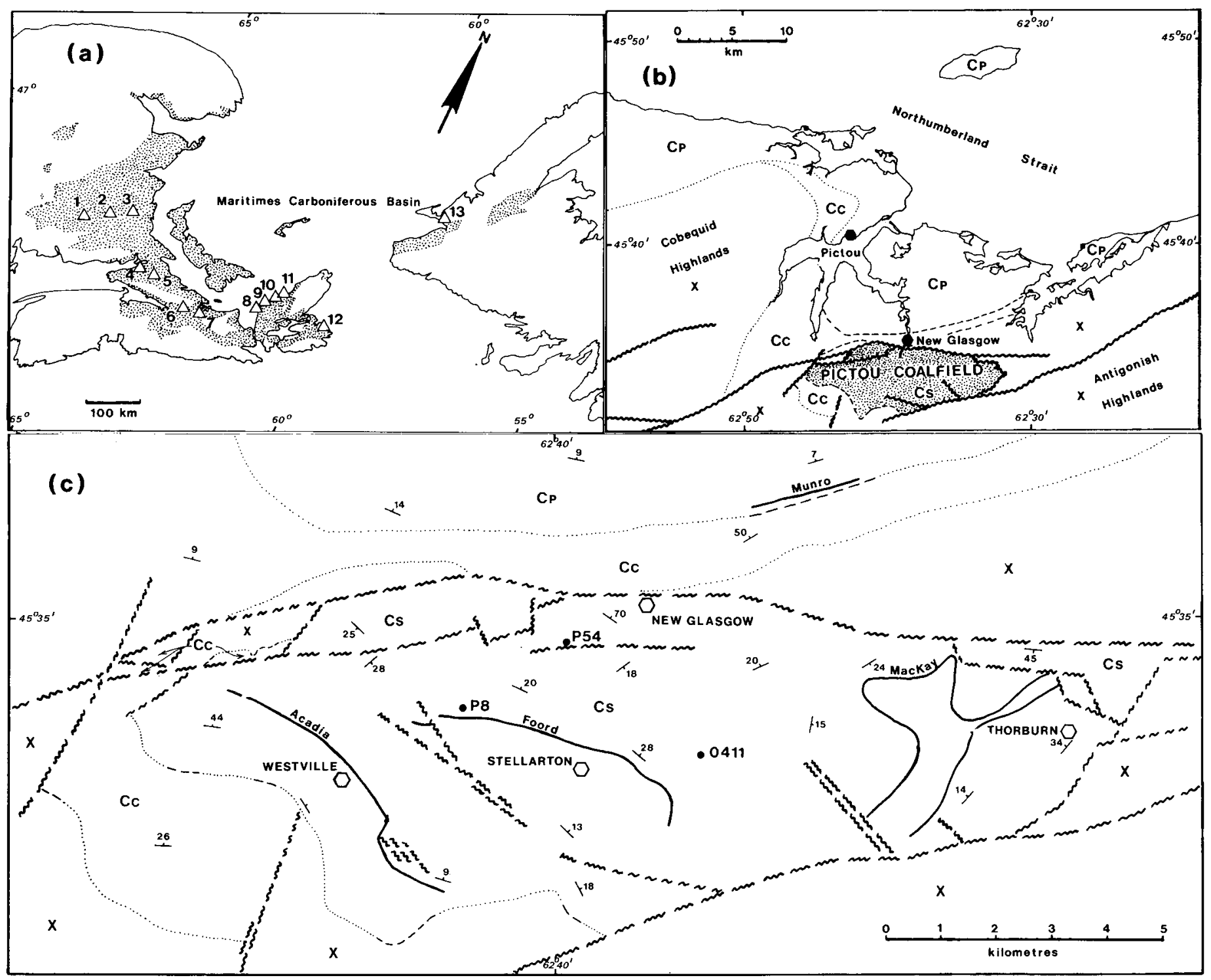

Fig. 1. (a) Coal deposits of the Northem Appalachians: (1) Minto, (2) Lake Stream, (3)Beersville, (4) Joggins - River Herbert, (5) Springhill, (6) Debert - Kemptown, (7) Pictou, (8) Port Hood, (9) Mabou, (10) Inverness, (11) St. Rose - Chimney Comer, (12) Sydney, (13) St. George's. (b) Geological sketch map of north-central Nova Scotia showing location of the Pictou Coalfield. $C_{p}=$ Pictou Group; $C_{s}=$ Stellarton Formation; $C_{c}=C u m b e r l a n d$ Group; $\mathrm{X}=$ Older strata. (c) Sketch map of the Pictou Coalfield showing fault pattems and surface traces of some major coal seams.

Conventionally, coal facies studies have been based on lithotype or microlithotype analysis (e.g., Calder, 1979; Hacquebard and Donaldson, 1969). However, coal facies analysis from maceral data provides an attractive alternative because such data are increasingly available, and are easily quantified. Diessel (1986) recently demonstrated how ratios of specific maceral combinations characterize particular peat-forming environments (Fig. 2). He defined two indices: (1) the tissue preservation index (TPI), a ratio of tissue-bearing macerals in which structure is preserved to those in which it is not; and (2) the gelification index (GI), a ratio of gelified to non-gelified macerals. TPI varies with the proportion of woody to herbaceous plant material, chiefly a function of environment and geological age. GI varies with diagenetic conditions. It approximates vitrinite - inertinite ratio
(Harvey and Dillon, 1985), a measure of redox conditions during peat accumulation. Both indices are affected by flooding and drying.

Sample preparation and petrographic examination were done by $\mathrm{M}$. Tomica at the Institute of Sedimentary and Petroleum Geology. The liptinite and inertinite maceral classifications outlined by Bustin et al. (1985) were followed. Vitrinite macerals were distinguished as vitrinite $A$ (clean banded vitrinite) and vitrinite $B$ (matrix vitrinite). From the maceral data, petrographic variation diagrams and coal facies diagrams (Yeo et al., 1988) were constructed following the methods of Diessel (1986). From these, changes in depositional and diagenetic conditions can be inferred. 
COAL FACIES (after Diessel, 1986)

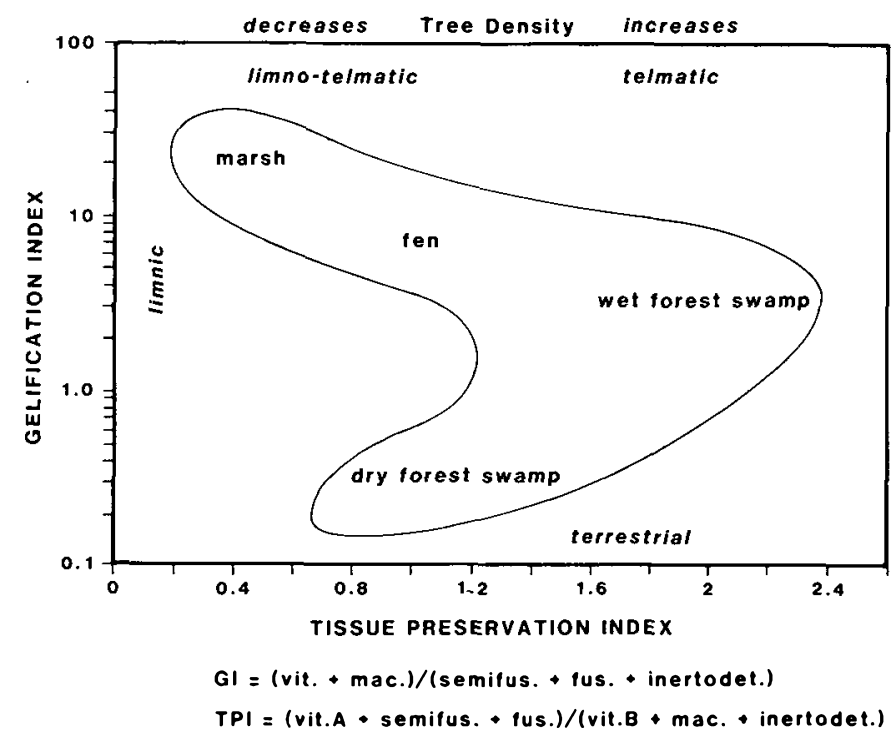

Fig. 2. Coal facies diagram (after Diessel, 1986). Although the fields of various plant communities indicated here are based on investigations of Permian coals in eastem Australia, they should be applicable to other coals since the component indices are not species dependent, but simply measures of degree of tissue breakdown, and of the proportion of woody plants in the original peat-forming plant assemblage. This is supported by the good agreement between environments indicated by lithotypes (Calder, 1979) and by coal facies analysis in this study. Gelification index (GI) reflects diagenetic conditions, while tissue preservation index (TPI) reflects the proportions of herbaceous and woody plants (i.e., plant communities).

\section{GEOLOGY OF THE PICTOU COALFIELD}

Resurgent interest in the coal and oil shale potential of Pictou Coalfield has led to recent studies of its structural geology (Gao, 1987; Yeo and Gao, 1986, 1987), stratigraphy (Snow, 1988; Yeo, 1985; Naylor and Smith, 1986), palynology (Dolby, 1986, 1987, 1988), and organic geochemistry (Birk and Pilgrim, 1986; Naylor and Smith, 1986; Kalkreuth and Macauley, 1987), as well as investigations of the coals and oil shales. Much new information has resulted from recent diamond drilling.

The oldest rocks recognized in the Pictou Coalfield belong to the early Namurian Canso Group (Bell, 1940; Fralick and Schenk, 1981). These reddish brown and grey fluvial sandstones and shales are unconformably overlain by reddish shales, sandstones and minor conglomerates of the Cumberland Group, deposited during Westphalian B to early Westphalian C time (Bell, 1940). Within the Stellarton Graben these strata are conformably or disconformably overlain by the Stellarton Formation (informal name proposed for the Stellarton Series of Bell, 1940), while north of the graben, they are overlain conformably or disconformably by the Merigomish Formation (informal name proposed for the Pictou Group in Stellarton Gap). The stratigraphy of these two coal-bearing formations is summarized in Figure 3.
The Stellarton Formation is a thick sequence of grey and red shales and sandstones with minor conglomerate (Fig. 3). The greybeds, which predominate in the Stellarton Formation, are interpreted as lacustrine and deltaic deposits, while the redbeds are interpreted to be floodplain and fluvial deposits (Yeo and Gao, 1987; and others). Contacts between the members are probably highly diachronous. Coarse-grained clastics are most prevalent towards the graben margins. The economic seams are restricted to the Stellarton greybeds.

The partly coeval Merigomish Formation is a predominantly grey sequence of stacked channel sandstones alternating with thick shales. These strata are interpreted as deposits of vertically aggrading rivers (D'Orsay et al., 1986; Yeo and Gao, 1987). They contain minor coals and oil shales.

\section{COALS OF THE PICTOU COALFIELD}

More than 20 coal seams have been recognized in the Pictou Coalfield. At least 12 of these have been extensively mined. The coals are of regionally anomalous rank (Hacquebard, 1984; Yeo et al., 1988). Most are of high volatile A bituminous rank, but one is of medium volatile bituminous rank (Hacquebard, 1984). The coals are characterized by low, but variable sulphur (0.5-3.3\%), and relatively high ash content (10.3-34.6\%), according to Chesal (1982).

Hacquebard and Donaldson (1969) described the Pictou coals in a classic paper on coal depositional environments. They showed that they become thicker and that mineral matter declines towards the center of the basin. They reported the coals to be petrographically uniform, except for their highly variable clastic component. The microbanding typical of the Pictou coals was shown to be due to alternating thin vitrinite and silt laminae. Partly on the basis of the microbanding and high mineral matter content the Pictou coals were interpreted to be hypautochthonous deposits (Hacquebard and Donaldson, 1969).

The Acadia, Foord, and MacKay seams were selected for study as respectively representative of the lower, middle, and upper coal-bearing greybed members of the Stellarton Formation (Fig. 3). Preliminary results of petrographic studies of these coals have been reported by Yeo et al. (1988). Although all of the seams are of generally duroclaritic character (i.e., vitrinite > inertinite > liptinite), their composition is variable (Yeo et al., 1988 , Figs. 4,5). Vitrinite and inertinite generally vary inversely. The relative proportions of vitrinite $A$ and $B$ vary laterally. The dominant inertinite macerals are fusinite, inertodetrinite, and semifusinite. The dominant liptinite macerals are sporinite, cutinite and liptodetrinite. Alginite and lamalginite are commonly present in low abundance.

Coal facies plots (Diessel, 1986) based on maceral analyses of the Pictou coals are interpreted to indicate deposition under wetland conditions ranging from limnic through fen to wet forest swamp (Yeo et al., 1988, Fig. 6). Tissue preservation index (TPI) ranges more widely than gelification index (GI). Cyclic shifts in TPI reflect changes in the abundance or preservation of woody plants, in tum probably controlled by rising and falling water table. 


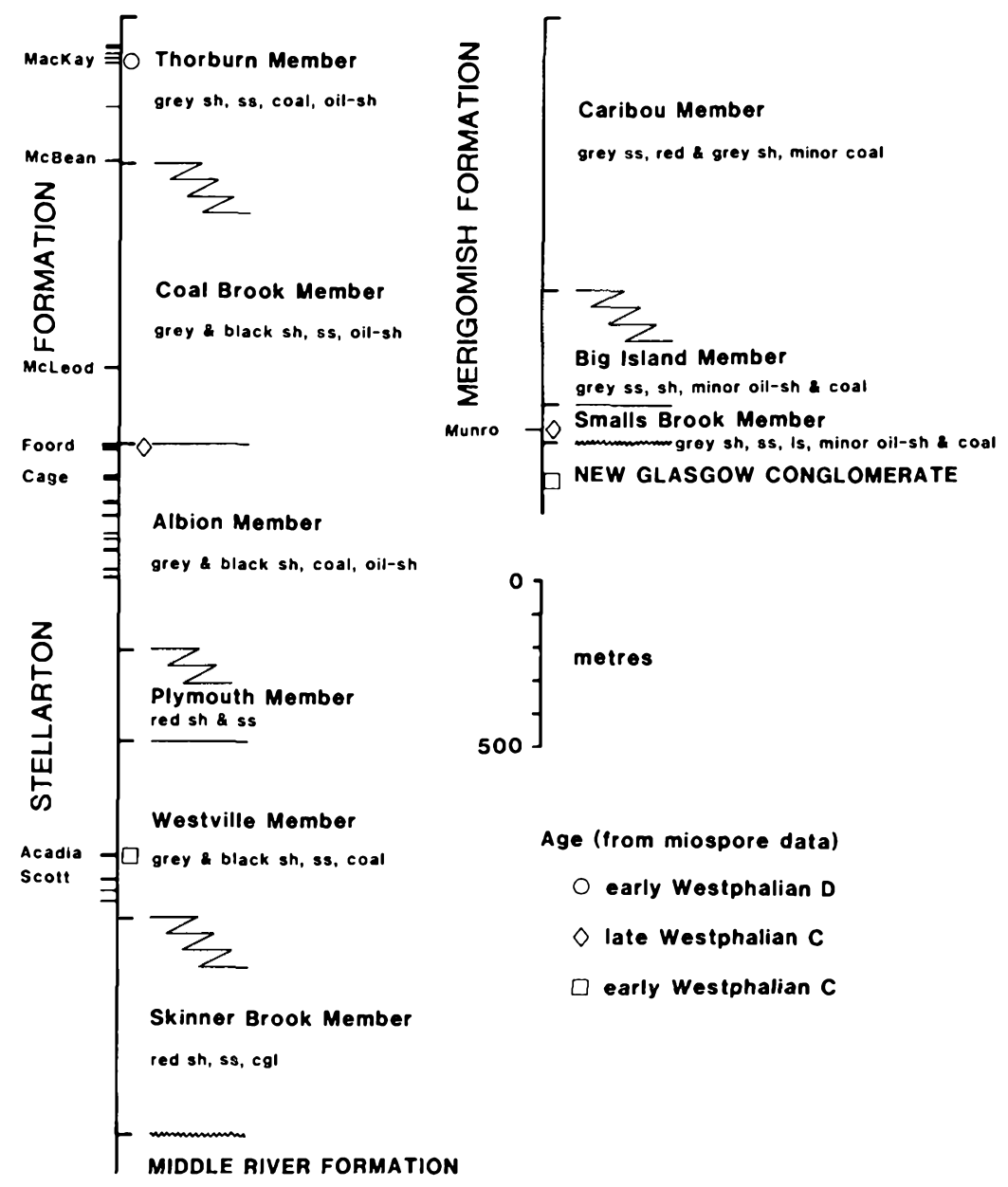

Fig. 3. Stratigraphic columns for the Stellarton and Merigomish Formations. Aggregate thickness shown is based on maximum measured thickness for each member (Yeo and Gao, 1987). Coal seams and miospore ages (Dolby, 1986, 1987) are indicated. The Foord seam marks the top of the Albion Member.

\section{THE FOORD SEAM}

\section{(a) Stratigraphic Setting}

The Foord seam marks the top of the Albion Member (Fig. 3 ; Bell, 1940). It is the uppermost and most extensive of a series of coal seams interbedded with grey shales and minor sandstones. It is also the thickest, up to $13 \mathrm{~m}$. Miospores from the Foord seam indicate a lower late Westphalian Cage (Dolby 1987, 1988). The seam was sampled in three boreholes: P-8, P-54, and 0411 (Fig. 1c).

The southwestern borehole, P-8, was drilled in an area of old workings northwest of Stellarton. Here the Foord seam is separated into two leaves or panels by $2.6 \mathrm{~m}$ of grey and black shale. Splitting of the seam in this area was noted by Hacquebard and Donaldson (1969). The lower leaf is $5.4 \mathrm{~m}$ thick and overlies $2.9 \mathrm{~m}$ of grey and black shale above interbedded grey sandstone and shale. The upper leaf is $4 \mathrm{~m}$ thick and is overlain by grey and black shales.

The northwestern borehole, DDH P-54, lies $2250 \mathrm{~m}$ northeast of P-8 and $3200 \mathrm{~m}$ northwest of 0411 . The Foord seam here is $9.2 \mathrm{~m}$ thick. It overlies $17 \mathrm{~m}$ of upward fining, plane-laminated dark grey to black mudstone and grey siltstone above interbed- ded, fine-grained, plane-, wavy- and ripple-laminated grey sandstone and mudstone. It is overlain in ascending order by mudstone, thin oil shale, and interbedded mudstone and sandy mudstone. Black mudstones with coaly laminae immediately underly and overly the coal.

The eastern borehole, DDH 0411, lies $4450 \mathrm{~m}$ ESE of P-8. Here the seam is $8.3 \mathrm{~m}$ thick. It overlies grey and black mudstone with minor coaly shale interbeds. It is separated from an overlying rider seam by $7 \mathrm{~m}$ of grey, irregularly laminated, upward coarsening siltstone with interbedded, laminated, organic-rich shales in the upper part. The rider (not described here) is about $0.7 \mathrm{~m}$ thick. It is overlain by $2 \mathrm{~m}$ of laminated organicrich shale, overlain in turn by grey, laminated siltstone.

The fine-grained clastics are interpreted as prodelta or lacustrine deposits, while the interbedded sandstones and mudstones are interpreted as delta interdistributary deposits. The sequence described above, of coal above lacustrine clastics, in turn overlying deltaic strata (in DDH P8 and P54), suggests that the Foord seam developed above an abandoned micro-delta "plain." Peat accumulation was probably terminated by renewed basin subsidence marked by delta regression (see Hacquebard and Donaldson, 1969, Fig. 12). 


\section{(b) Previous Petrographic Work}

The only seams of this coalfield previously subjected to detailed petrographic study (i.e., microlithotypes) are the Scott (Hacquebard and Donaldson, 1969) and the overlying Acadia seam (Hacquebard and Avery, 1976).

Calder (1979) described vertical and lateral lithotype variation in the Foord seam in a test pit $80 \mathrm{~m}$ south of borehole P-8. He recognized cyclic lithotype sequences. A complete cycle, in ascending order, comprises: vitrain, clarodurain, durain, fusain, shaly coal, and coaly shale. At least ten such cycles, up to $3.8 \mathrm{~m}$ thick, were identified. Following the method of Tasch (1960), Calder (1979) inferred from the cyclic alternation of lithotypes that depositional conditions ranged from wet forest swamp (vitrain) to open reed swamp (claro-durain and durain), oxidizing shallow lakes (fusain), and reducing deeper lake conditions (shaly coal and shale). Each cycle represents an episode of transgressive, peat-swamp drowning.

\section{(c) Petrography}

The mineral matter profiles (Fig. 4) confirm that the Foord seam comprises alternating coal-rich and shaly coal or coaly shale beds (Calder, 1979). It is difficult to correlate individual plies with confidence because they commonly pinch out over short distances (Calder, 1979), but general trends can be identified. A thin basal interval characterized by upward increase in mineral matter content (i.e., transgression) can be recognized in the profiles from P-8 and P-54. This is followed by a thick interval, recognizable in all three profiles, in which mineral matter content shows both cyclic and overall decrease (i.e., regression). An upper interval characterized by upward increase in ash content (i.e., transgression) can clearly be identified only in the profiles from P-54 and 0411. No clear correspondence between mineral matter and maceral content was recognized.

Inspection of the maceral group profiles (Fig. 4) reveals that the Foord seam has the duroclaritic character (i.e., vitrinite $>$ inertinite > liptinite) typical of the Pictou coals (Hacquebard and
Donaldson, 1969; Yeo et al., 1988). The proportions of vitrinite and inertinite are roughly the same in all three profiles, but the proportion of liptinite is variable. Vitrinite and inertinite vary inversely.

In the lower leaf of DDH P-8, vitrinite averages $64 \pm 5 \%$; in the upper leaf it similarly averages $65 \pm 4 \%$. Vitrinite $B$ is the predominant vitrinite form in both leaves. Inertinite averages $25 \pm 5 \%$ in the lower leaf and $21 \pm 3 \%$ in the upper. Fusinite and inertodetrinite are the chief inertinites in both leaves. Liptinite averages $12 \pm 2 \%$ in the lower leaf and $14 \pm 2 \%$ in the upper leaf. Sporinite is the main liptinite maceral. Minor alginite or lamalginite are present throughout most of the section.

In P-54, vitrinite averages $63 \pm 10 \%$. As in $\mathrm{P}-8$, vitrinite $\mathrm{B}$ is the dominant vitrinite form. Inertinite averages $22 \pm 10 \%$. As in P-8, fusinite and inertodetrinite are the chief inertinites. Fusinite is anomalously high (34\%) at the base of the section. Liptinite averages $15 \pm 5 \%$. Sporinite and cutinite are the main liptinite macerals. Alginite and lamalginite are present throughout most of the section.

In DDH 0411 , vitrinite averages $74 \pm 14 \%$. Unlike the other two profiles, vitrinite $A$ is the dominant vitrinite form here. Inertinite averages $22 \pm 14 \%$. As in the other profiles, fusinite and inertodetrinite are the main inertinite macerals. Fusinite is the dominant maceral in a thin band near the top to the section. Liptinite averages $4 \pm 5 \%$. Liptodetrinite is the main liptinite maceral. Alginite and lamalginite are present at intervals.

\section{(d) Depositional Environment}

The predominance of vitrinite suggests that wet forest swamp conditions were most prevalent, while relatively high liptinite abundance in the two westerly profiles (P8 and P54) suggests that herbaceous material may be a more significant component (i.e., stronger limnic influence) there (Bustin et al., 1985).

The cyclicity identified by Calder (1979) is corroborated by results of the maceral studies. Coal facies diagrams (Fig. 5) show cyclic alternation of wet forest swamp, fen (mixed marsh and forest conditions), marsh, and lake conditions. TPI is more
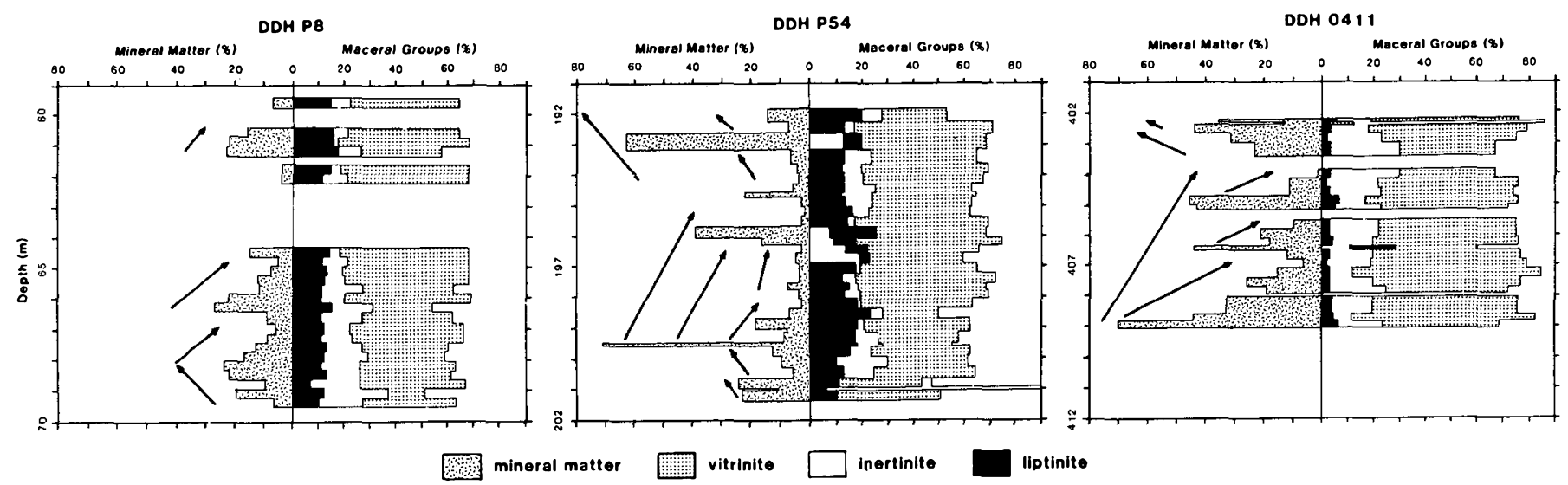

Fig. 4. Three petrographic profiles through the Foord seam. DDH P-54 and 0411 were sampled by lithotype, but DDH P-8 was sampled in arbitrary 1 foot increments. The lower proportion of liptinite in profile 0411 suggests less limnic influence on peat accumulation here than further west. Arrows indicate temporal trends. Gaps in each sequence are unsampled intervals or stoney partings. 
Foord Seam
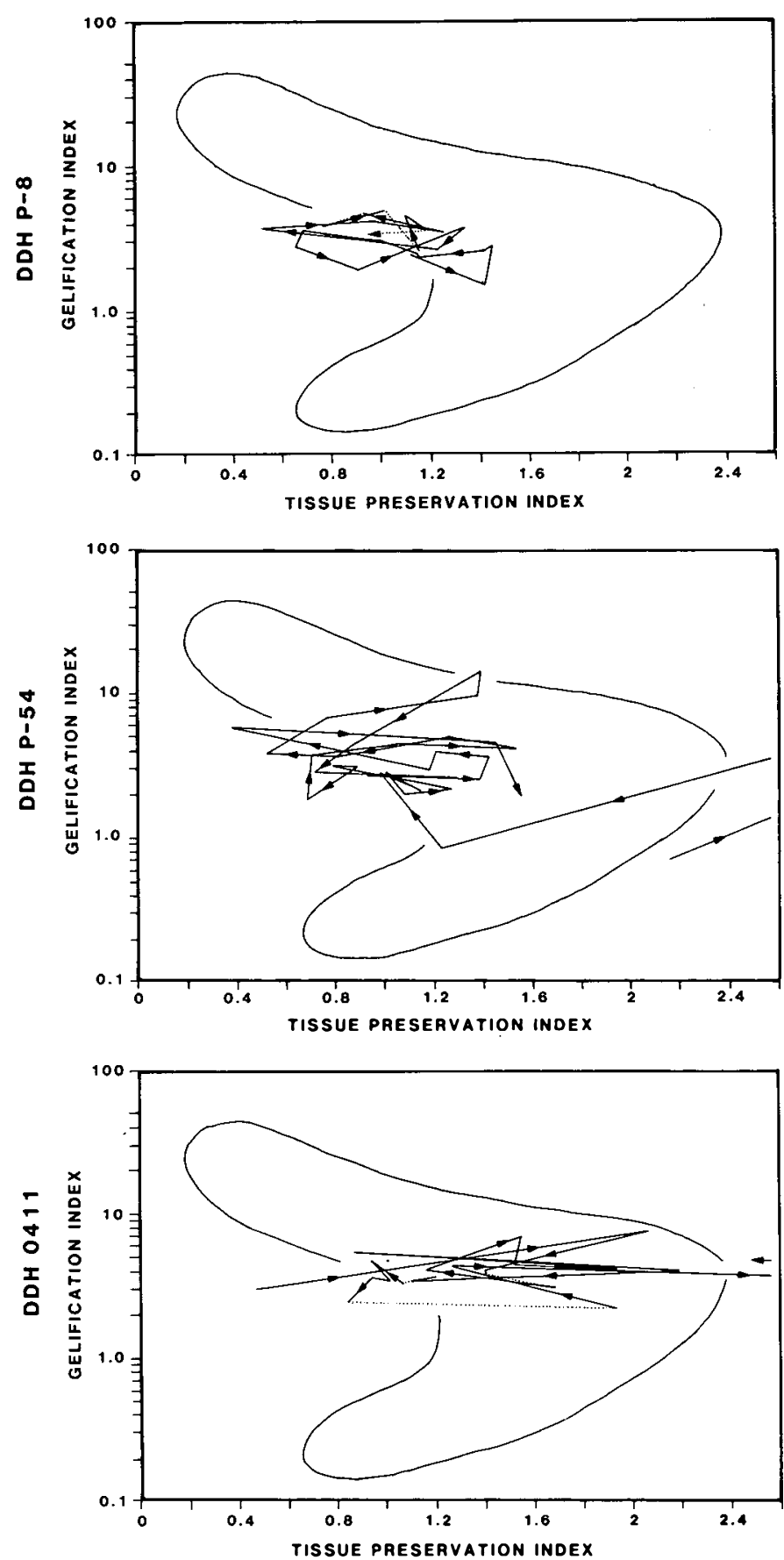

Fig. 5. Coal facies diagrams for the Foord seam. Sample gaps are indicated by dotted lines. Cyclic variation from limnic through fen (mixed woody and herbaceous plants) to wet forest swamp conditions is consistent with paleoenvironmental interpretation from lithotypes (Calder, 1979) and with interpretation of the coal seam as a peat accumulation on a lakeshore or abandoned delta. Note that more telmatic conditions were developed in the easternmost section (DDH 0411).

variable than $\mathrm{GI}$. The narrow range within which $\mathrm{GI}$ varies, and its similarity in all three sections suggests that redox conditions did not change very much during peat accumulation, and that such conditions were fairly uniform throughout the area of peat accumulation. The wide range in TPI suggests sequential devel- opment of plant communities, probably controlled by rising and falling water table. Floras dominated by herbaceous plants appear to have predominated in the western part of the basin (DDH P8 and P54), whereas woody and herbaceous plants appear to have alternated in dominance towards the east (DDH 0411).

The wider fluctuation in composition of peat-forming plant communities in the eastern part of the basin suggested by the coal facies plot for DDH 0411 is supported by alternation of the three environmentally controlled phases recognized in late Westphalian miospore assemblages (i.e., Lycospore, Transition, and Incursion phases of Smith, 1962) in this seam profile (Yeo et al., 1988, Fig. 4f). Only two (Transition and Incursion phases) predominate in the miospore assemblages from DDH P54 (Dolby, 1988).

Like the petrographic variations from which they were derived, facies variations are difficult to correlate in detail. Broad trends in facies variation, corresponding roughly to the long term transgression - regression cycles indicated by variation in mineral matter, can be recognized, however (Fig. 6). The general decrease in TPI upwards in the lower part of all three profiles suggests a long term shift toward less telmatic conditions, probably due to a rise in water table (i.e., basin subsidence) on which short term fluctuations are superimposed. This flooding culminated with development of the split in the seam shown in P-8. Increasing GI in profiles P8 and P54 over the same interval suggest that conditions became more reducing in the western part of the basin, while decreasing GI over this interval in profile 0411 suggests that conditions farther east became more oxidizing (increased fresh water influx?). In the upper part of the seam, TPI shows a tendency to increase, reflecting more telmatic conditions. Shifts in GI in the upper part of the seam are difficult to correlate, suggesting local variability in fresh water influx and redox conditions.

The correspondence between the TPI profile for the lower leaf of DDH P8 and the lithotype section from a nearby pit (Calder, 1979, Fig. 8) supports the use of coal facies diagrams such as these in environmental interpretation. (Sample gaps in the upper leaf preclude its correlation.) The three coaly intervals recognized by Calder correspond to peaks on the TPI profile. All fall within the "fen" part of the coal facies field (Fig. 2), which corresponds reasonably to the open reed swamp environment suggested by lithotypes. The lowest coal-rich interval has the highest TPI, reflecting the strongest telmatic influence. In Calder's (1979) section this interval contains a thick vitrain band, suggesting a period of forest swamp conditions.

\section{CONCLUSIONS}

This study is the first basin-scale documentation of petrographic variability within a seam from the Pictou Coalfield. The only other northern Appalachian coal seam to have received detailed study is the Harbour seam in the Sydney Coalfield (Cameron, 1971).

Individual plies cannot be correlated with much confidence, but trends in mineral matter content and coal facies over larger intervals can be recognized on a basin scale. 

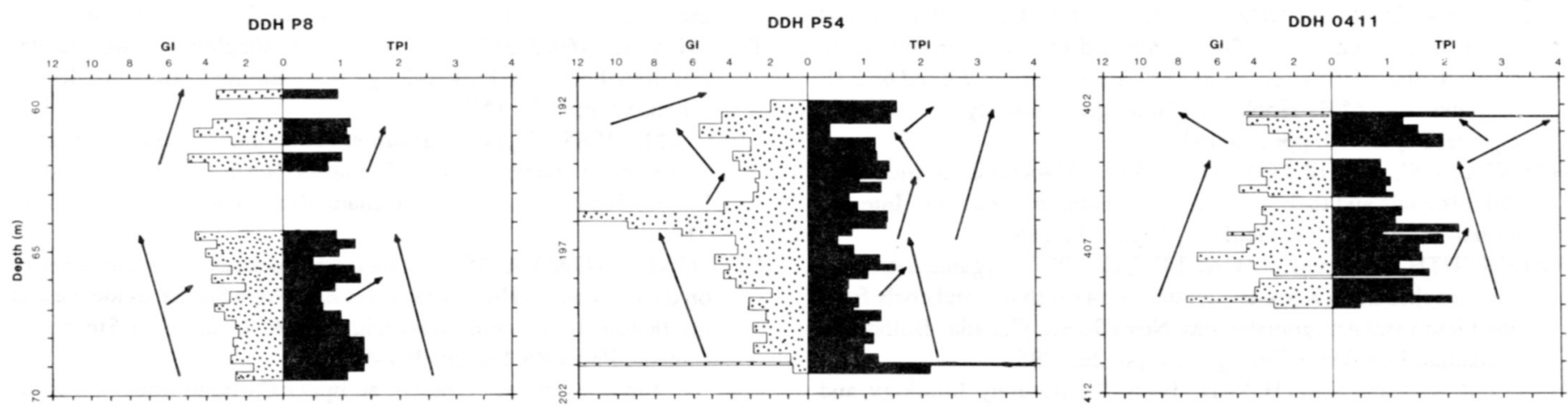

Fig. 6. Coal facies profiles for the Foord seam. See Figure 4 for explanation of GI (gelification index) and TPI (tissue preservation index). Arrows indicate temporal trends.

The Foord seam was deposited in a lake margin setting on an abandoned lower delta plain. Peat accumulated under cyclic, limnic, fen, and wet forest swamp conditions. The cycles reflect paludification and basin subsidence.

Cycles of peat accumulation occurred on at least two scales. Long-term cycles (thousands of years) reflect episodic basin subsidence. Short-term cycles (hundreds of years) may reflect localized influx of clastics and relatively oxidized fresh water and changing plant communities.

Inferences about the depositional environment of individual plies within the Foord seam, made here from coal facies analyses based on maceral data (Diessel, 1986), are consistent with interpretations from lithotypes.

\section{ACKNOWLEDGEMENTS}

Thanks are due to Arden Thompson of Suncor Limited for allowing sampling of DDH 0411, and to Kevin Gillis of Nova Scotia Department of Mines and Energy for sampling P8 and P54; to Wolfgang Kalkreuth and Maria Tomica of the Institute for Sedimentary and Petroleum Geology for facilitating and carrying out the petrographic examination; to Kevin Gillis, Rob Naylor, and Bill Smith of the Coal Section, Nova Scotia Department of Mines and Energy for many discussions, and to Peter Hacquebard and John Calder for their constructive reviews of this paper. This work was done as part of the Stellarton Basin Analysis Project under the Canada - Nova Scotia Mineral Development Agreement 1984-1989.

BELL, W.A. 1940. The Pictou Coalfield, Nova Scotia. Geological Survey of Canada, Memoir 225, $160 \mathrm{p}$.

BIRK, D. and PILGRIM, J.C. 1986. Geochemical analysis of coals and organic-rich sediments: Stellarton Basin Project. Geological Survey of Canada, unpublished report.

BUSTIN, R.M.,CAMERON, A.R.,GRIEVE, D.A., and KALKREUTH, W.D. 1985. Coal Petrology - Its Principles, Methods, and Applications. Geological Association of Canada, Short Course Notes, 3, $230 \mathrm{p}$.

CALDER, J.H. 1979. Effects of Subsidence and Depositional Environment on the Formation of Lithotypes in Hypautochthonous Coal of the Pictou Coalfield. Nova Scotia Department of Mines and Energy, Paper 79-6, 23 p.

CAMERON, A.R. 1971. Some petrological aspects of the Harbour coal seam, Sydney Coalfield, Nova Scotia. Geological Survey of Canada Bulletin, $175,74 \mathrm{p}$.

CAMERON, J.M. 1974. The Pictonian Colliers. Nova Scotia Museum, $355 \mathrm{p}$.

CHESAL, S. 1982. Pictou Coalfield Project: an evaluation of coal resources in the Westville, Stellarton, and Thorburn districts of the Pictou Coalfield. Nova Scotia Department of Mines and Energy, unpublished report, $95 \mathrm{p}$.

DIESSEL, C.F.K. 1986. On the correlation between coal facies and depositional environment. In Advances in the Study of the Sydney Basin. Proceedings of the 20th Newcastle Symposium, New South Wales, Australia, pp. 19-22.

DOLBY, G. 1986. A palynological study of sixty samples from the late Westphalian coal measures in the Stellarton Gap area, northem Nova Scotia. Geological Survey of Canada, unpublished report, 48 p.

. 1987. Palynological analysis of samples from the Stellarton basin, Nova Scotia. Geological Survey of Canada, unpublished report, $48 \mathrm{p}$.

. 1988. Palynological analysis of samples from the Stellarton Basin, Canfield Creek, and Mabou Mines, Nova Scotia. Geological Survey of Canada,unpublished report, $23 \mathrm{p}$.

D'ORSAY, A.M., NAYLOR, R.D., SMITH, W.D., BLACK, M.C., and PALMER, S.E. 1986. Models for coal exploration - Trenton Syncline area, Nova Scotia. Nova Scotia Department of Mines and Energy, Tenth Annual Open House and Review of Activities, Program and Summaries, Information Series 12, pp. 11-13.

FRALICK, P.W. and SCHENK, P.E. 1981. Molasse deposition and basin evolution in a wrench tectonic setting: the late Paleozoic eastern Cumberland Basin, Maritime Canada. In Sedimentation and Tectonics of Alluvial Basins. Edited by A.D. Miall. Geological Association of Canada, Special Paper 23, pp. 77-98.

GAO, R. 1987. Deformation Characteristics of the Eastern Cobequid and Hollow Fault Zones and Stellarton Basin, Nova Scotia. M.Sc. thesis, University of New Brunswick, 227 p.

HACQUEBARD, P. 1979. A geological appraisal of the coal resources of Nova Scotia. Canadian Institute of Mining and Metallurgy, Transactions, 82, pp. 48-59.

1984. Coal rank changes in the Sydney and Pictou coalfields of Nova Scotia; cause and economic significance. Canadian Institute of Mining and Metallurgy Bulletin, May, pp. 33-40.

HACQUEBARD, P. and AVERY, M. 1976. On the petrography, rank, and predicted coke stabilities of Acadia seam coal, Pictou coalfield, Nova Scotia. Atlantic Geoscience Centre Technical Report (unpublished) 11-E/10-76-1, $25 \mathrm{p}$. 
HACQUEBARD, P. and DONALDSON. 1969. Carboniferous coal deposits associated with flood plain and limnic environments in Nova Scotia. In Environments of Coal Deposition. Edited by E.C. Dapples and M.E. Hopkins. Geological Society of America, Special Paper 114, pp. 143-191.

HARVEY, R.C. and DILLON, J.W. 1985. Maceral distributions in Illinois coals and their paleoenvironmental implications. International Journal of Coal Geology, 5, pp. 141-165.

KALKREUTH, W.D. and MACAULEY, G. 1987. Organic petrology and geochemical (Rock-Eval) studies on oil shales and coals from the Pictou and Antigonish areas, Nova Scotia, Canada. Bulletin of Canadian Petroleum Geology, 35, pp. 263-295.

NAYLOR, R.D. and SMITH, W.D. 1986. Stratigraphy, lithology, and composition of the Stellarton Group oil shales, Pictou County, Nova Scotia. Nova Scotia Department of Mines and Energy, Open File No. 86-051, 114 p.

SNOW, R.J. 1988. The depositional environment of the late Carboniferous coal-bearing upper Thorbum member of the Stellarton group, Pictou Coalfield, New Glasgow, Nova Scotia. M.Sc. thesis, Acadia University, 156 p.

SMITH, A.H.V. 1962. The paleoecology of Carboniferous peats based on the miospores and petrography of bituminous coals. Proceed- ings of the Yorkshire Geological Society, 33, pp. 423-474.

TASCH, K.H. 1960. Dire Moglichkeiten der Fluzgleich stellung uneter Zuhilfenahme von Flögbildungs diagrammen. Bergbau Rundschau, 12, pp. 153-157.

YEO, G.M. 1985. Upper Carboniferous sedimentation in northem Nova Scotia and the origin of Stellarton Basin. Current Research, Part B, Geological Survey of Canada Paper, Paper 85-1B, pp. 511518.

YEO, G.M. and GAO, R. 1986. Late Carboniferous dextral movement on the Cobequid - Hollow fault system, Nova Scotia: evidence and implications. Current Research, Part A, Geological Survey of Canada, Paper 86-1A, pp. 399-410.

1987. Stellarton Graben: an upper Carboniferous pull-apart basin in northem Nova Scotia. In Sedimentary Basins and BasinForming Mechanisms. Edited by C. Beaumont and A.J. Tankard. Canadian Society of Petroleum Geologists, Memoir 12, pp. 299309

YEO, G.M., KALKREUTH, W.D., DOLBY, G., and WHITE, J.C. 1988. Preliminary report on petrographic, palynological, and geochemical studies of coals from the Pictou Coalfield, Nova Scotia. Current Research, Part B, Geological Survey of Canada, Paper 88-1B, pp. 29-40. 